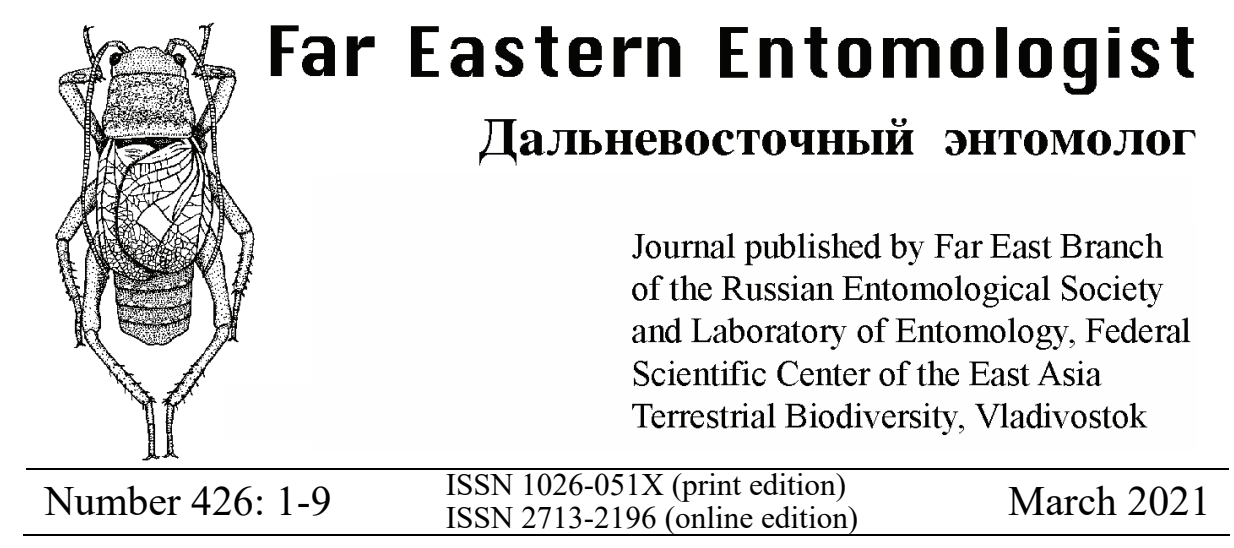

https://doi.org/10.25221/fee.426.1

http://zoobank.org/References/BA42F3B8-83FE-4ABA-913B-5653C4C3F2AD

\title{
A NEW SPECIES OF SOFT-WINGED FLOWER BEETLE OF THE GENUS KUATUNIA EVERS, 1949 (COLEOPTERA: CLEROIDEA, MALACHIIDAE) FROM NEPAL
}

\author{
S. E. Tshernyshev ${ }^{1,2, *)}$, M. V. Shcherbakov ${ }^{2)}$
}

1) Institute of Animal Systematics and Ecology, Russian Academy of Sciences, Siberian Branch, Novosibirsk, 630091, Russia. * Corresponding author, E-mail: schsch@mail.ru

2) Tomsk State University, Lenina prospekt 36, Tomsk 634050, Russia.

Summary. A new malachiid beetle species Kuatunia andreasi Tshernyshev, sp. n. is described from Nepal (Karnali Province). Figures of the external appearance, elytral apices, and genitalia of the male are provided for the new species. A key to all species of the genus Kuatunia Evers, 1949 is given.

Key words: Coleoptera, Malachiidae, Kuatunia, taxonomy, new species, key, Nepal, Karnali Province.

С. Э. Чернышёв, М. В. Щербаков. Новый вид жуков малашек рода Kuatunia Evers, 1949 (Coleoptera: Cleroidea, Malachiidae) из Непала // Дальневосточный энтомолог. 2021. N 426. С. 1-9.

Резюме. Из провинции Карнали в Непале описан новый вид жуков малашек трибы Ebaeini (Coleoptera: Malachiidae) - Kuatunia andreasi Tshernyshev, sp. n. Даны иллюстрации внешнего вида жука, вершины надкрылий и гениталий самца. Приведена определительная таблица видов рода Kuatunia Evers, 1949. 


\section{INTRODUCTION}

The genus Kuatunia Evers, 1949 has been reviewed with a discussion of differential characters and position of the genus in the tribe Ebaeini (Tshernyshev, 2012), three new species were described from China and north-eastern Russia (Tshernyshev (2012) and Nepal (Tshernyshev (2015), and two Ebaeini species were transferred from Ebaeus Erichson to Kuatunia (Asano, 2013), namely K. chibaensis (Nakane, 1989) and K. horaianus (Nakane, 1991). Both these species belong to oblongula species-group, the members of which look similar but differ in the shape of the apical impression and appendage in elytra of males and the colouration of dark and light parts of body. As was shown (Tshernyshev (2015), three species distributed in Japan require further investigation, since $K$. horaianus (Nakane) should have been considered as a synonym of $K$. oblongula oblongula (Kiesenwetter, 1874), but $K$. oblongula chujoi Wittmer, 1954 is valid taxon. However, Asano et al., (2018) solved this problem, their excellent colour photographs of the male's external appearance and scanned apices of elytra present good differential characters to three independent species $K$. horaianus (Nakane), $K$. oblongula (Kiesenwetter) and $K$. chujoi Wittmer, 1954. A further species from Taiwan was also transferred by Asano (2015) from Ebaeus Erichson to Kuatunia alutaceus (Wittmer, 1986), increasing the number of species in Kuatunia Evers to 17.

A new Kuatunia species was found amongst soft-winged flower beetle material collected in Nepal by scientists from the Naturkundemuseum in Erfurt, Germany. Previously, two species were described in the genus Kuatunia from Nepal: $K$. bullosa Wittmer, 1995 and K. matthiasi Tshernyshev, 2015. The new species looks similar to K. bullosa Wittmer, 1995, but has wide yellow colouration of elytral apices, the ultimate ventrite has a different shape that lacks sharp processes on the tips of the distal side, a narrow elongate aedeagus, and shape of impressions and appendages in elytral apices. A description of a new species is given below, and an improved key to all species of Kuatunia is also provided.

\section{MATERIAL AND METHODS}

For descriptions, special male structures and genitalia were studied, the "special male structures" here referring to the impressed and complicatedly depressed apices of elytra each possessing an appendage of a unique shape, and a comb above the 2nd tarsomere in anterior legs. Illustrations for the holotype of Kuatunia andreasi Tshernyshev, sp. n. have been prepared from a specimen from near Churta village, Karnali Province, Nepal.

The beetles were studied using an Amscope trinocular stereomicroscope (Ultimate Trinocular Zoom Microscope 6.7X-90X Model ZM-2TY), and digital photographs were taken using a Carl Zeiss Stemi 2000 trinocular microscope and the AxioVision programme. Male genitalia, embedded in DMHF (Dimethyl hydantoin formaldehyde), were mounted onto a transparent card and pinned under the specimen mounted with water-soluble glue. All material studied is deposited in the collections of Naturkundemuseum, Erfurt, Germany (NMEG). 


\section{TAXONOMY}

Family Malachiidae Fleming, 1821

Subfamily Malachiinae Fleming, 1821

Tribe Ebaeini Portevin, 1931

Genus Kuatunia Evers, 1949

Type species: Kuatunia klapperichi Evers, 1949, by original designation.

SPECIES INCLUDED. There are 19 species in the genus: Kuatunia andreasi Tshernyshev, sp. n. (Nepal: Karnali Province); K. australis Wittmer, 1991 (Madagascar); K. alutaceus (Wittmer, 1986) (Taiwan: Nantou); K. bullosa Wittmer, 1995 (Nepal: 120 km S Kathmandu); K. chibaensis (Nakane, 1989) (Japan: Honshû); K. emeiensis Wittmer, 1995 (China: Sichuan); K. guilinensis Wittmer, 1995 (China: Guangxi); K. horaiana (Nakane, 1991) (Japan: Honshû); K. klapperichi Evers, 1949 (China: Fujian); K. matthiasi Tshernyshev, 2015 (Nepal: Seti Province); K. nigroopaca Wittmer, 1995 (China: Sichuan); K. nordica Tshernyshev, 2012 (Russia: Taimyr, Yakutia); K. oblongula (Kiesenwetter, 1874) (Japan); K. chujoi Wittmer, 1954 (Japan); K. oloyensis Wittmer, 1999 (Russia: Transbaikalia, Yakutia, Magadanskaya Oblast); K. sichuana Wittmer, 1995 China: (Sichuan); K. soppongensis Wittmer, 1995 (Thailand); K. yamawakii (Nakane, 1985) (Japan: Meshima and Kamikoshiki Islands); K. wolongensis Tshernyshev, 2012 (China: Wolong National Nature Reserve).

The distribution of the genus Kuatunia is remarkable in that it ranges from Madagascar through South East Asia to the Arctic region of North Asia. Among the species of the genus, six are known from China and Taiwan, four from Nepal, two from Russia, five from Japan, one from Thailand and one from Madagascar.

NOTES. A valuable contribution by Plonsky (2016) clarified the date of publication of the first description of the genus Kuatunia Evers in "Entomologische Blätter" since it was earlier taken to be "1945-48" from the journal's front page; actually the journal was printed in 1949 , so the correct and valid designation should be "Kuatunia Evers, 1949".

\section{Key to the species of the genus Kuatunia}

1. Pronotum uniformly dark, the same colouration as elytra (black, dark-brown or with metallic luster) ... 2

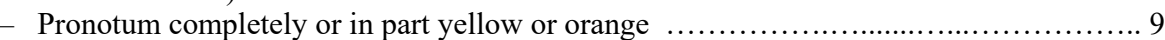

2. Head completely dark, elytra black ............................................. 3

- Head completely or in part yellow or yellow-brown, elytra black, or partially yellow or pale-yellow .....

3. Legs dark except for lighter, brownish tarsi ................................................................... 4

- Apices of femora, tarsi and tibiae yellow. Antennae yellow, dorsal part of 1 st segment above, and segments 6-11 almost completely darkened. Male apical sternite with a narrow horn, elytral apices with dorsally curved fine flexure (Tshernyshev 2012a: fig. 15)

K. australis Wittmer, 1991 
4. Only 1st to 4th antennomeres more or less yellowish at the inner side. Tarsi black; in males, tarsal comb light-brownish. Apical tergite narrow, elongate and rounded, elytral apices with an oval lamella with a curved plate over it (Tshernyshev 2012a: fig. 20) .......

K. nigroopaca Wittmer, 1995

- Only 1st to 3rd antennomeres red-yellow and slightly darkened dorsally, 4th segment brown, remaining segments dark; tarsi brownish, anterior reddish. In male, apical sternite cut, almost square-shaped, elytral apices shaped like tiny processes closed in half-circles (Tshernyshev 2012: fig. 19)

K. klapperichi Evers, 1949

5. Elytra completely black, including elytral apices; antennae and legs completely yellow. In male, structure of elytral apices as incrassate flexure curved dorsally and anteriorly, with deep impression inside (Tshernyshev 2012a: figs. 2, 3) ..... K. nordica Tshernyshev, 2012

- Elytra, at least to some extent, pale coloured laterally and/or apically

6. Legs and antennae monochromously yellow or with brownish tarsi, lateral sides of elytra and pronotum lightened, in male impressions in elytral apices yellow, upper margin of the impression pale-yellow, lower part of the impression black-brown, appendage black, apices of the elytra pointed

K. oblongula (Kiesenwetter, 1874)

- Tibiae and sides of femora in posterior legs black, antennae yellow or black-brown distally

7. Intermediate tibiae and dorsal sides of anterior tibiae black, apical third of elytra paleyellow, dorsal side of the 1st antennomere and 5th to 11th antennomeres dark brown, apices of elytra depressed, with semi-transparent vertical appendage as wide bottle-shape (see Asano et al., 2018: figs 6, 17) in middle, apical margin transverse and twice depressed, rounded

K. chibaensis (Nakane, 1989)

- Anterior tibiae yellow or yellow-brown, intermediate tibiae completely yellow or yellowbrown, or with darkened apices, antennae monochromously yellow-brown or darkened distally

8. Antennae and anterior and intermediate legs monochromously yellow-brownish, tarsi sometimes darker; elytra black with v-shape yellow colouration of apices black near suture; elytral apices wide, depressed, with slightly stretched tips and black narrow bottle-shape appendages near suture, (see Tshernyshev, 2012a: fig. 21; Asano et al., 2018: figs 7, 18)

K. chujoi Wittmer, 1954

- Anterior and intermediate legs yellow-brownish, intermediate tibiae darkened distally, basal antennomeres yellow-brown, dorsal side of the 1st antennomere and completely 5th to 11th antennomeres dark brown, apical quarter of elytra with depressions and appendages yellow, apices strongly depressed and weakly impresses with triangular upper side above the impression, appendage as wide triangle (see Asano et al., 2018: figs $8,19)$.

K. horaianus (Nakane, 1991)

9. Pronotum partially darkened

10

- Pronotum completely light, yellow or orange 11

10. Pronotum almost completely black except basal slope and posterior angles light yellow, head and scutellum black, antennomeres 1 st to 3rd yellow on the inner side, remaining black, legs black with slightly lighter tarsi; elytra black with whitish apices and brownish suture. In male, transversal impression of elytral apices light, incrassate flexures black (see Tshernyshev 2012a: fig. 17)

K. emeiensis Wittmer, 1995

- Pronotum orange with a longitudinal black spot in the middle; scutellum yellow at base and darkened distally, head yellow with dark occiput, antennae yellow, slightly darkened from outer side, apical segments almost completely dark; legs completely yellow; elytra black with narrow yellow lateral stripes slightly widening towards middle, suture lightbrown. In male inner part of impression in elytral structures yellow (see Tshernyshev 2012a: fig. 22) K. oloyensis Wittmer, 1998 
11. Elytra completely black 12

- Elytra black with light spots on apices, in some specimens with narrow light stripes laterally, either on humeri or on suture

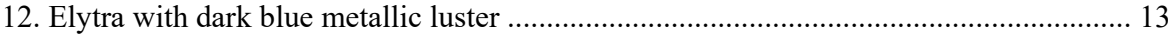

- Elytra free from metallic luster; head black; mouthparts, palps and pronotum yelloworange; antennomeres 1 st to 4 th yellowish darkened on outer sides, remaining black; scutellum and elytra completely black, legs black with all knees, tarsi and intermediate coxae yellow. Male elytral apices as concave and impressed plate apically (Tshernyshev 2012a: fig. 9)

K. wolongensis Tshernyshev, 2012

13. Pronotum orange, legs black with male tarsal comb brownish. Male elytral apices widely impressed with a large leaf-shaped longitudinal appendage in the middle (Tshernyshev 2012a: fig. 18) ..... K. guilinensis Wittmer, 1995

- Pronotum yellow-orange, legs yellow with darkened tarsi. Male elytral apices widely impressed twice stretched and impressed, with a small longitudinal appendage in the middle (Fig. 2)

K. matthiasi Tshernyshev, 2014

14. Head and legs monochromously yellow or orange

Head black, legs almost completely or at least femora dark

15. Head, maxillary palps, pronotum and legs completely orange, scutellum and elytra dark, elytra with narrow yellow stripe on base and humeri and yellow apices, antennomeres 1st to 4 th orange, dark, 5th slightly darkened, remaining black. In male, specific structure as shallow trapeziform impression near the elytral apices with thin ribs on the external and inferior sides, and a thin small appendage near the suture (Tshernyshev 2012a: fig. 24) ...

K. soppongensis Wittmer, 1995

- Head, maxillary palps, pronotum and legs completely yellow or yellow-brown ............. 16

16. Head and legs yellow, antennae yellow with dorsally darkened 4th to 11th antennomeres, apical quarter of elytra pale yellow, light colouration continued in lateral sides to epipleura, appendage in impression dark, shaped alike carafe with bottleneck and plug (see Asano et al., 2018: figs 10,21) K. yamawakii (Nakane, 1985)

- Head and legs yellow-brown, antennae yellow-brown with light-brown 7th to 11th antennomeres, apical quarter of elytra black-brown with pale-yellow semi-lunar or cymbiform upper margin of the impression, appendage in impression as transparent oval and apically curved vertical plate (see Asano, 2015: figs 15, 16) ........... K. alutaceus (Wittmer, 1986)

17. Legs completely black, anterior slightly lighter; head, maxillary palps and scutellum black, elytra black with orange spots apically, pronotum orange, antennomeres 1st to 3rd yellowish, completely black on inner sides. In male, specific structures in each elytral apex with an entangled three-cells impression with a wide longitudinal upper appendage in the middle (Tshernyshev 2012a: fig. 23) ............................ K. sichuana Wittmer, 1995

- Legs black-brown with light-brown or yellow tarsi or only femora dark brown ............ 18

18. Legs black with light brown tarsi and anterior femora, head and palpi black, pronotum yellow-orange, elytra dark with small yellow apical spots; antennomeres 1st and 2nd black but yellowish spotted on outer sides, remaining black. In male, specific structures in elytral apices as complicated three-cell impression from outer side, and deeply impressed flexure near the suture with wide, longitudinal, upper appendage near the suture (Tshernyshev 2012a: fig. 16)

K. bullosa Wittmer, 1995

- Legs black with yellow tarsi and tibiae, head black, palpi light-brown, pronotum yelloworange, elytra dark with yellow apical quarter; antenna light-brown with 1st and 2nd antennomeres yellowish ventral side. In male, complicatedly modified dorsally, strongly impressed and with depressed outer margin, each with round lamellate appendage on pedicle in upper side of the impression near suture (Figs 7,8)

K. andreasi Tshernyshev, sp. $\mathbf{n}$. 
Kuatunia andreasi Tshernyshev, sp. $\mathbf{n}$.

http://zoobank.org/NomenclaturalActs/C878E71E-0A90-448D-9E3B-79F0ECAACA75

Figs $1-17$

TYPE MATERIAL. Holotype: $\widehat{\jmath}$, Nepal: Prov. Karnali, Churta, W Munigaon, 2900-2600 m, 2909'49" N, 82³1'09" E, 19.V 1995, leg. A. Weigel (NMEG). Paratypes: the same label, $1 \hat{\delta}, 1$ (

DESCRIPTION. Holotype, male (Figs 1, 2). Body elongate, parallel, weakly widened posteriorly.

Head almost completely black with mouthparts, palpi, labrum and antennae light-brown. Pronotum yellow, scutellum black, elytra black with yellow apices. Underside of the body dark brown with partly yellow prothorax and abdomen; legs light brown with black basal portion of intermediate and posterior femora, coxae and trochanters light brown in anterior legs and black-brown with light brown apices in intermediate and posterior legs. Surface evenly covered with dense, fine and adpressed light pubescence, lacking erect dark hairs. Vesicles pale yellow; thoracic mesepimera black-brown.

Head narrower than pronotum, eyes slightly protruding, small, oval; front flat; genae short and straight; clypeus narrow, transverse, straight; labrum short, transverse; palpi simple with cylindrical pointed apical segment and narrow transverse 2nd palpomere; surface of head shining, sparsely and finely punctured lacking microsculpture, pubescence dense, short and adpressed.

Antennae filiform, $1.4 \mathrm{~mm}$ long, expanded over the base and not reaching the middle of the elytra; 1st antennomere enlarged and slightly clavate, 2nd antennomere triangular with rounded angles, 3rd-10th antennomeres triangular, 11th antennomere 1.4 times as long as the 10th, and 1.3 times shorter than the 1st segment, oval, evenly sinuate at apex; surface evenly covered with short, light erect pubescence.

Pronotum transverse, anterior margin slightly convex, posterior margin straight; lateral sides flattened and slightly dilated just behind the middle, evenly rounded before; posterior side and basal flattened parts of the lateral sides distinctly marginate; surface finely and sparsely punctured, with indistinct microsculpture, dull, with fine depressed light pubescence.

Scutellum small, rectangular with rounded angles, transverse, almost completely covered by pronotum, sparsely punctured and covered with sparse adpressed pubescence, dull.

Elytra oblong, subparallel, slightly widened posteriorly, at base somewhat wider than pronotum; humeri distinct, not protruding; apices sinuate, flattened and stretched, complicatedly modified dorsally, strongly impressed, each with round lamellate appendage on pedicle in upper side of the impression near suture (Figs 7,8); surface semi-shining, densely punctured, with distinct microsculpture, evenly covered with dense, short and fine semi-erect pubescence.

Hind wings normally developed.

Legs moderate in length, thin and elongate; posterior femora not reaching elytral apices; tibiae thin, straight, posterior slightly curved and possess narrow longitudinal 


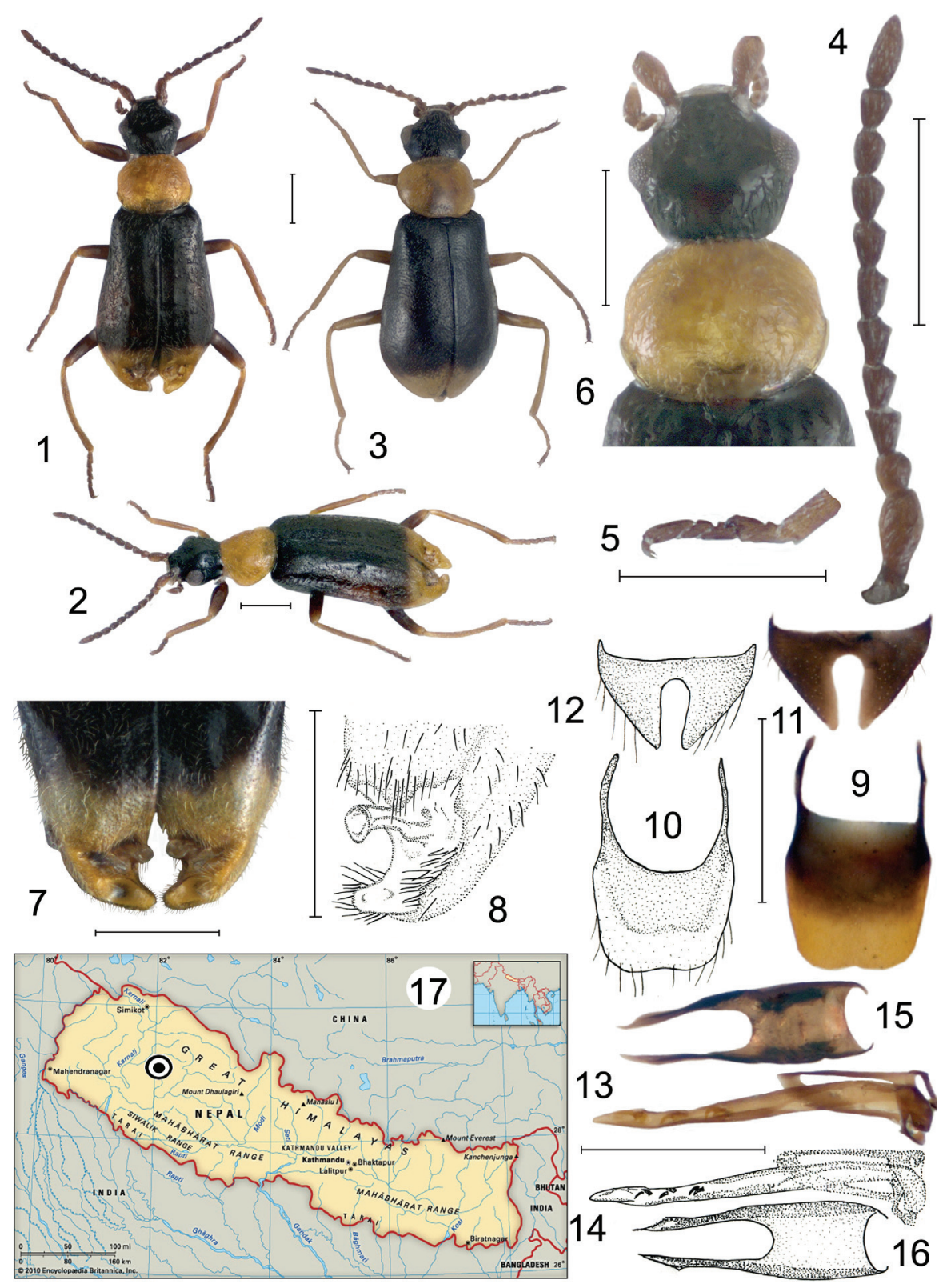

Figs 1-17. Kuatunia andreasi Tshernyshev sp. n., holotype, male (1, 2-16), allotype, female (3) distribution map (17). 1, 3 - beetle dorsally; 2 - beetle lateral; 4 - left antenna; 5 right anterior tarsus; 6 - head, pronotum and scutellum dorsally; 7 - elytral apices dorsally; 8 - apex of right elytra sublateral; 9, 10 - apical tergite; 11, 12 - apical sternite; 13, 14 aedeagus, subdorsal; 15, 16 - tegmen; 17 - distribution map. Scale bar $0.5 \mathrm{~mm}$. 
carina along tibia not reaching base; femora slightly compressed, simple; all tarsi 5 -segmented, narrow, second tarsomere in anterior tarsi with small comb above expanding over the 3rd tarsomere (Fig. 5); claw-segment longest and 1.5 times longer than the 1st segment in posterior legs, and slightly longer in anterior and intermediate tarsi, equal to 1 st plus 2 nd combined in all legs; claws small, curved, narrow and sharp, with small round membrane at base.

Ventral body surface densely punctured, with distinct microsculpture, evenly covered with fine, depressed pubescence; metathorax slightly swollen, simple; pygidium (apical tergite) wide, elongate and longitudinal, evenly rounded distally and slightly emarginate at middle of tip (Figs 9, 10); 8th ultimate ventrite (apical sternite) narrow, transversal, evenly sinuate apically and extremely deep emarginate at middle (Figs 11, 12); aedeagus simple, narrow and elongate, narrowed and sharp apically and slightly curved dorsally at base, with small pointed lamella, with threefour curved spines in internal sac in apical part of the aedeagus (Figs 13, 14); tegmen elongate, with elongate parameres with widened tips, and wide base (Fig. $15,16)$.

Length $2.8 \mathrm{~mm}$, width (at elytral base) $0.8 \mathrm{~mm}$.

Female. Differs from male by somewhat slender antennae, absence of comb in anterior tarsi, elytra strongly widened posteriorly, and slightly narrowed at the apex with simple apices lacking impressions or appendages; length $2.6 \mathrm{~mm}$, width (at elytral base) $0.7 \mathrm{~mm}$.

COMPARISON. The new species is similar to K. bullosa Wittmer, 1995 but differs in its wide yellow colouration of elytral apices, ultimate ventrite lacking sharp processes on the tips of distal side, a narrow elongate aedeagus and shape of impressions and appendages in elytral apices.

DISTRIBUTION. Nepal: Karnali Province (Fig. 17).

ETYMOLOGY. The species is named in honour of Andreas Weigel (Wernburg, Germany), an authority on Xylobiontic beetles, and specialist in Cerambycidae (Lamiinae of Asia), my good friend who collected a lot of marvellous Malachiidae species from different areas of the World.

\section{ACKNOWLEDGMENTS}

I am grateful to Andreas Weigel (Wernburg, Germany), who collected this new species in Nepal and to Dr Matthias Hartmann and Dr Andreas Kopetz (the Naturkundemuseum, Erfurt), who provided me with this material on loan. Thanks are also due to Prof. Mark Seaward (Bradford University, U.K.) for advice and linguistic revision of the text. This study was supported by the Russian Foundation for Basic Research (grant No. 19-04-00465-a), as well as by the Program of Basic Scientific Research (FNI) of the State Academies of Sciences, project No. FWGS-2021-0004.

\section{REFERENCES}

Asano, M. 2013. New combinations and redescriptions of six species of the tribe Ebaeini Portevin (Coleoptera, Malachiidae) in Japan. Japanese Journal of Systematic Entomology, 19(2): $275-284$. 
Asano, M. 2015. Taxonomic Notes on Some Malachiid Beetles of Taiwan, with Description of a New Species of the Genus Intybia Pascoe (Coleoptera: Malachiidae). Japanese Journal of Systematic Entomology, 21(1): 77-82.

Asano, M., Ikeda, H., Kamezawa, H. \& Nomura, Sh. 2018. Revision of Six Species of the Subtribe Ebaeina of Japan, with Description of a New Species (Coleoptera: Melyridae). Japanese Journal of Systematic Entomology, 24(1): 141-149.

Evers, A.M.J. 1949. Neue Malachiidae. Entomologische Blätter, [1945-1948]: 41-44, 4960.

Plonski, I.S. 2016. Studies on the genus Intybia Pascoe, 1866 (Coleoptera: Malachiidae) V. Contribution to internal classification and taxonomy, with faunistic and nomenclatorial notes. Zeitschrift der Arbeitsgemeinschaft Österreichischer Entomologen, 68: 17-38.

Tshernyshev, S.E. 2012. Two new species of soft-winged flower beetles of the genus Kuatunia Evers, 1945-48 (Coleoptera, Malachiidae) from China and northeastern Russia. Zootaxa, 3191: 56-64.

Tshernyshev, S.E. 2015. A new species of soft-winged flower beetles of the genus Kuatunia Evers, 1945-48 (Coleoptera, Cleroidea, Malachiidae) from Nepal. Zootaxa, 3941(2): 255-260. DOI: http://dx.doi.org/10.11646/zootaxa.3941.2.6 